\title{
Longitudinal comparison between plasma and seminal HIV-1 viral loads during antiretroviral treatment
}

\author{
Comparação longitudinal entre cargas virais seminais e plasmáticas do HIV-1 \\ durante terapia anti-retroviral
}

\author{
Lauro Ferreira da Silva Pinto Neto, ${ }^{1,2}$, Nilo F.R. Vieira ${ }^{2}$, Moacir Soprani $^{2}$, Carla B. Cunha ${ }^{1}$, \\ Valéria P. Cabral' ${ }^{1}$ Reynaldo Dietze ${ }^{1}$ and Rodrigo Ribeiro-Rodrigues ${ }^{1}$
}

\begin{abstract}
This study was designed to investigate the impact of anti-retroviral therapy on both plasma and seminal HIV-1 viral loads and the correlation between viral loads in these compartments after treatment. Viral load, CD $4^{+}$ and $C D 8^{+} T$-cell counts were evaluated in paired plasma and semen samples from 36 antiretroviral therapy-naïve patients at baseline and on days 45, 90, and 180 of treatment. Slopes for blood and seminal viral loads in all treated patients were similar $(\mathrm{p}=0.21)$. Median HIV-1 RNA titers in plasma and semen at baseline were 4.95 $\log _{10}$ and $4.48 \log _{10}$ copies/ml, respectively. After 180 days of therapy, the median viral load declined to $3.15 \log _{10}$ coples $/ \mathrm{ml}$ (plasma) and $3.2 \log _{10}$ copies $/ \mathrm{ml}$ (semen). At this timepoint 22 patients presented HIV-1 viral load below 400 copies $/ \mathrm{ml}$ in either plasma or semen, but only 9 had viral loads below 400 copies $/ \mathrm{ml}$ in both compartments.
\end{abstract}

Key-words: Viral load. Semen. HIV-1. Antiretroviral therapy. Plasma.

Resumo Este estudo foi desenhado para investigar o impacto do tratamento com anti-retrovirais na evolução das cargas virais plasmáticas e seminais do HIV-1. A carga viral do HIV-1 e a contagem de linfócitos $T C D 4^{+} e$ $C D 8^{+}$foi determinada em amostras pareadas de sangue e sêmen de 36 pacientes virgem de tratamento nos dias 0, 45, 90 e 180 após o início da terapia. As curvas de declínio das cargas virais plasmática e seminal foram semelhantes ( $\mathrm{p}_{\mathrm{a}}$ 0.21). As medianas da carga viral plasmática e seminal no pré-tratamento (dia 0) foram $4.95 \mathrm{e}$ $4.48 \log _{10}$ cópias $/ \mathrm{ml}$, respectivamente. Seis meses após o início da terapia, a mediana da carga viral plasmática era $3.15 \log _{10}$ cópias $/ \mathrm{ml}$ e a seminal $3.2 \log _{10}$ cópias $/ \mathrm{ml}$. Neste mesmo periodo, 22 pacientes apresentavam carga viral abaixo de 400 cópias/ml no plasma elou sêmen, enquanto apenas 9 pacientes apresentavam carga viral abaixo do limite de detecção nos dois compartimentos.

Palavras-chaves: Carga viral. Sêmen. HIV-. Terapia antiretroviral. Plasma.

Despite the fact that HIV-1 was first recovered from semen samples in 1984, and sexual activity continues to be the most common form of HIV transmission, little is known about the impact of seminal viral load on HIV-1 infection ${ }^{18}$. A wide variety of biological and behavioral factors have been associated with the risk of sexual transmission of HIV-1 ${ }^{14}$. Recently, a strong association between HIV-1 plasma viral load and the risk of heterosexual transmission was reported ${ }^{13}$. It has been suggested that high levels of HIV-1 replication probably contribute to both rapid disease progression and enhanced sexual transmission ${ }^{3518}$. Small short- term studies have demonstrated that antiretroviral therapy reduces both blood and seminal viral load and may diminish HIV transmission ${ }^{6718}$. We have shown that the correlation between plasma and seminal viral loads in therapy-naïve patients decreases in parallel with declining CD4 cell counts ${ }^{13}$.

The current study was conducted to prospectively evaluate the impact of antiretroviral therapy on HIV viral loads in plasma and semen of antiretroviral-naïve HIV-1+ patients; and, to compare viral loads in both semen and plasma compartments, with peripheral blood T-cell counts at baseline and during treatment.

\footnotetext{
1. Cellular and Molecular Immunology Laboratory, Núcleo de Doenças Infecciosas, Universidade Federal do Espírito Santo, Vitória, ES, Brazil. 2. Santa Casa de Misericórdia de Vitória, Vitória, ES, Brazil.

Address to: Dr. Rodrigo Ribeiro-Rodrigues. Núcleo de Doenças Infecciosas/CBM/UFES. Av. Marechal Campos 1468, Maruípe 29040-091 Vitória, ES, Brazil. Tel: 5527 335-7207, Fax: 5527 335-7204

e-mail: rodrigrr@ndi.ufes.br

Recebido para publicação em 15/4/2002

Aceito em 10/11/2003
} 


\section{MATERIAL AND METHODS}

Institutional Review Board. Prior to its implementation, this study was submitted and approved by the Biomedical Center Internal Review Board. A signed informed consent was obtained from all enrolled patients before their inclusion in the study.

Patients. The study population consisted of 36 consecutive adult anti-retroviral therapy-naïve HIV-1+ men attending the HIV clinic at Santa Casa de Misericórdia, Vitória. ES, Brazil, between March 1998, and July 1999. All patients were free of signs or symptoms of sexually transmitted diseases. Clinical staging was performed according to the CDC classification system ${ }^{2}$. These patients were treated with either two-drug (two nucleoside analogs reverse transcriptase inhibitors) or three-drug (two nucleoside analogs reverse transcriptase inhibitors plus one protease inhibitor or one non-nucleoside reverse transcriptase inhibitor regimens) schemes according to Brazilian Consensus on Antiretroviral Therapy, current at the time of the study ${ }^{10}$. After informed consent, all 36 patients were requested to donate blood and semen samples at baseline and 45, 90, and 180 days after beginning therapy.

Quantitation of CD4+ lymphocytes in blood samples. Blood was collected by venipuncture in Vacuntainer tubes (Becton Dickinson, Franklin Lakes, New Jersey, USA) using $\mathrm{K}^{3}$-EDTA as an anticoagulant and processed within 4 hours of collection. Peripheral blood CD4 and CD8 cell counts per microliter were determined by flow cytometry (FACScount, Becton \& Dickinson, Mountain View, CA, USA) using standardized protocol recommended by the manufacturer. Results were expressed as mean \pm standard deviation.

Quantitation of HIV-1 RNA in blood and seminal plasma samples. Plasma was obtained from $\mathrm{K}^{3}$ EDTA-treated whole blood samples centrifuged at 600 $\mathrm{xg}$ for 7 minutes and stored in aliquots at $-70^{\circ} \mathrm{C}$ within 4 hours of collection. In order to ensure the quality of semen samples, patients were asked to comply with a 72-hour sexual abstinence prior to sample collection. Semen samples were processed within $4 \mathrm{~h}$ of ejaculation as described by Vernazza et $\mathrm{al}^{18}$. Briefly, the total volume of semen was measured and the sample diluted 1:2 with viral transport medium (plain RPMI $1640+1000 \mathrm{U} / \mathrm{ml}$ penicillin $+1000 \mathrm{mg} /$ $\mathrm{ml}$ streptomycin). Diluted sample was centrifuged at $1,600 \times g$ for $5 \mathrm{~min}$, and the supernatant was collected. Aliquots were stored at $-70^{\circ} \mathrm{C}$ until used for the quantification of HIV-1 RNA. Semen samples are referred to as seminal plasma. HIV-1 viral load in either blood plasma (PVL) or seminal plasma (SVL) were quantified by the NASBA method (Organon Teknika, Durham, North Carolina, USA ${ }^{4}{ }^{16}$. The detection limit of the assay was 400 HIV-1 RNA copies $/ \mathrm{ml}$. Both plasma and seminal viral load results were expressed as medians. In order to evaluate intersample variability in PVL and SVL, 2 consecutive paired blood and semen samples were collected and analyzed (interval of $11.2 \pm 7.5$ weeks between the two collection points) from 17 therapy-naïve patients before the treatment began.

Treatment. Antiretroviral regimen for each patient was selected by the physician in charge following the guidelines of the Brazilian Consensus on Antiretroviral Therapy in place at the time of the study. Twelve patients were treated with two nucleoside analog reverse transcriptase inhibitors ( 9 used AZT + ddl and 3 used AZT + ddC). Whereas, 24 patients were treated with three drugs, 2/24 patients were treated with nucleoside analogs (AZT + 3TC) and a non-nucleoside reverse transcriptase inhibitors (Efavirenz) and the remaining 22 patients were treated with two nucleoside analogs (AZT + 3TC) and a protease inhibitor (10 with Indinavir, 8 with Ritonavir and 4 with Nelfinavir). For further analysis and discussion of results, these patients were divided into those receiving two-drug regimens (12 patients) and those receiving three-drug regimens (24 patients). Patient compliance was encouraged and followed by the clinical team throughout the protocol.

Statistical analysis. Considering the non-normal distribution of RNA concentrations, confirmed by Kolmogorov-Smirnov tests, continuous variables were analyzed following log transformation and linear regression analysis by the Wilcoxon's test. Correlations between non-parametric variables (HIV-1 RNA titers on blood and semen, CD4 and CD8 counts) were evaluated using Spearman's rank correlation test. The decline of viral load slopes on blood plasma and semen samples were compared by multivariate analysis. All statistical analyses were carried out using SPSS 8.0 software (SPSS Inc) and by SAS (SAS institute Inc. SAS/STAT guide for personal computers, version 6 , Cary, NC, USA).

\section{RESULTS}

The mean age for the 36 enrolled patients was 33.7 \pm 9.6 years, with a predominance of Caucasians $(58.3 \%$, 21/36 patients). Twenty-three patients were homosexual/ bisexual, 9 were heterosexuals and 4 were intravenousdrug users. At baseline 7 patients $(19 \%)$ had CD4 cell counts higher than $500 \mathrm{cells} / \mu \mathrm{l}, 15(42 \%)$ had cell counts between 499 and $200 \mathrm{CD} 4$ cells/ $/ \mu$ and 14 (39\%) patients had CD4 counts less than 200 CD4 cells/ $\mu$ l.

Fourteen out of 36 patients were asymptomatic. Symptomatic patients most frequently were found to have weight loss greater than 10\%/cachexia (6 patients), pulmonary pneumocystosis (5 patients), herpes zoster 
(4 patients), tuberculosis (3 patients), cryptococcal meningitis (2 patients), neurotoxoplasmosis (1 patient), esophageal candidiasis (2 patients), recurrent bacterial pneumonia (1 patient), five patients presented more than one of the opportunistic infections/clinical manifestations described above.

The mean $\mathrm{CD}^{+}{ }^{+}$and $\mathrm{CD} 8^{+} \mathrm{T}$ cell counts, at baseline, were $313 \pm 242$ cells $/ \mathrm{ml}(32-964$ cells $/ \mu \mathrm{l})$ and 1,189 $\pm 486 \mathrm{cells} / \mathrm{ml}$ (266 - 2,292 cells/ $\mu \mathrm{l})$, respectively (Table 1). At 6 months of treatment CD4 ${ }^{+}$cell counts improved with antiretroviral therapy, patients with a mean increase of $123 \mathrm{CD}^{+}$cells/ $\mu \mathrm{l}$ (Table 1 and Figure 1A). Improvement in $\mathrm{CD}^{+}$and $\mathrm{CD}^{+} \mathrm{T}$ cell counts were significantly greater among patients taking 3-drug when compared to those on 2-drug combinations. After therapy began, CD4/CD8 T cell ratios improved at 90 and 180 days after initiation of antiretroviral therapy and were 0.30 , and 0.34 , respectively, when compared to the ratio at baseline $(C D 4 / C D 8=0.27)$.

HIV-1 RNA was detected and quantified at baseline on all blood and semen samples. Inter-sample variability in PVL and SVL was evaluated using 2 consecutive paired blood and semen samples collected from 17 treatment-naïve patients. Albeit PVL and SVL in these 17 patients were not significantly different ( $p=0.463$ and $p=0.906$, respectively), SVL samples presented a broader variation when compared to their paired PVL samples (data not shown).

Baseline PVL and SVL for all antiretroviral-naive patients studied were $4.95 \log _{10}$ copies/ml (3.51 - $5.92 \log _{10}$ copies $/ \mathrm{ml}$ ) and $4.48 \log _{10}$ copies $/ \mathrm{ml}(3.04-6.11 \mathrm{log} / \mathrm{ml})$, respectively. After therapy initiation, a significant reduction in plasma samples was observed $(p=0.000)$ : PVL at days 45,90 and 180 were $3.08,2.86$, and $3.15 \log _{10}$ copies/ $\mathrm{ml}$, respectively. A similar significant decrease was also observed for SVL at 45, 90, and 180 days of therapy (3.26, 2.47, and $3.2 \log _{10}$ copies $/ \mathrm{ml}$, respectively) (Table 1 and Figure 1B). Patients receiving 2-drug versus 3-drug regimen presented significant differences only on $P V L$ reduction $(p=0.011)$. However no statistical difference was seen between SVL reduction in patients receiving 2versus 3-drug regimens (Figure $1 \mathrm{~B}$ ). When all patients were considered, reduction rates in PVL and SVL were similar during treatment, as demonstrated by multivariate analysis $\left(\mathrm{F}_{3.210}=1.52 ; p=0.21\right)$ (Table 1 and Figure 2$)$.

Table 1 - Evolution of CD4 \& CD8 counts; plasmatic and seminal HIV-1 viral burden with therapy*.

\begin{tabular}{lcccc}
\hline & \multicolumn{4}{c}{ Timepoints } \\
\cline { 2 - 5 } & Baseline & 45 days & 90 days & 180 days \\
\hline CD4+ T cells & $313 \pm 242$ & $415 \pm 214$ & $437 \pm 227$ & $436 \pm 258$ \\
CD8 ${ }^{+}$T cells & $1189 \pm 486$ & $1608 \pm 1067$ & $1490 \pm 626$ & $1279 \pm 484$ \\
PVL & 4.95 & 3.08 & 2.86 & 3.15 \\
SVL & 4.48 & 3.26 & 2.47 & 3.20 \\
\hline
\end{tabular}

* CD4 \& CD8 cell counts are expressed as mean \pm standard deviation of cell counts $/ \mu l$.

PVL and SVL are expressed as medians of $\log _{10}$ copies $/ \mathrm{ml}$.
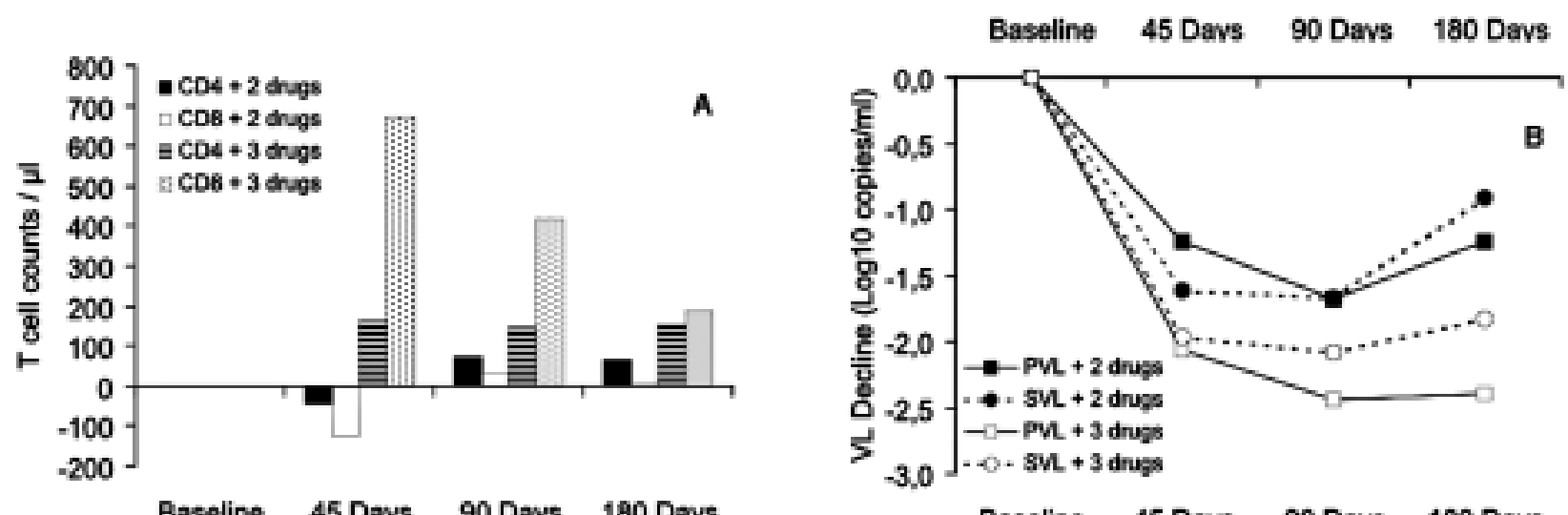

Figure 1 - A) Changes in CD4 and CD8 T cell counts before and during antiretroviral treatment with different drug schemes, and B) Changes in seminal and plasma HIV-1 viral load on patients receiving 2 - and 3 - drugs combination therapy. 


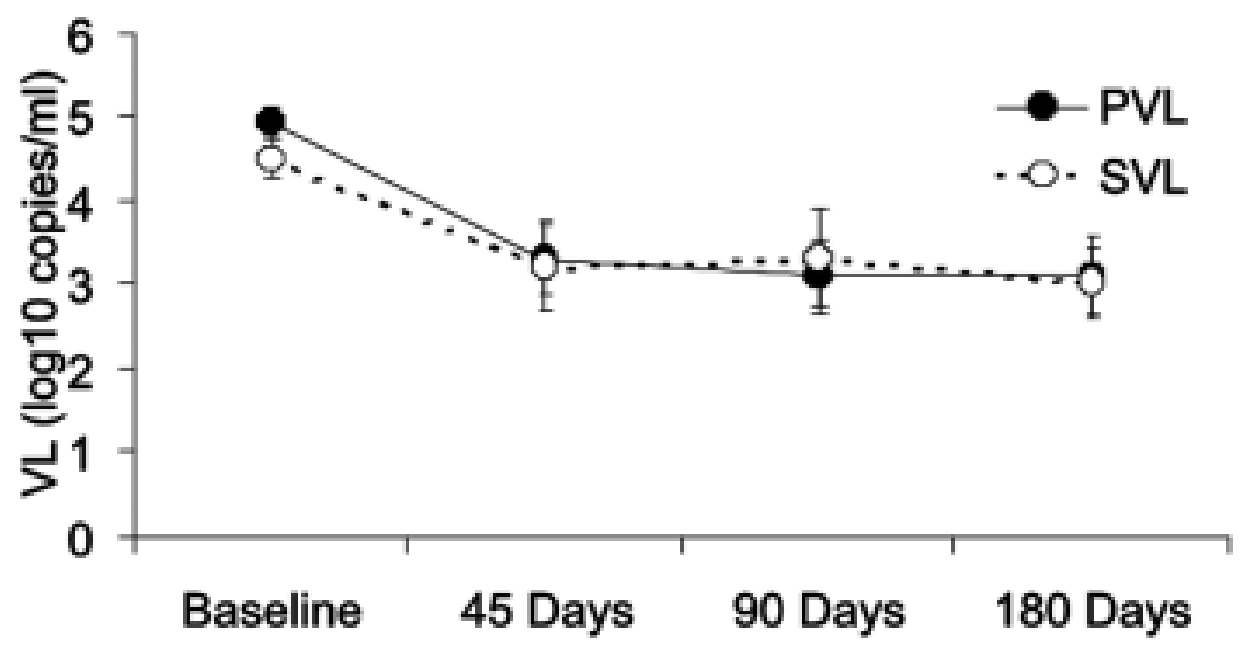

Figure 2 - Median HIV-1 viral load on both plasma and seminal samples from all 36 patients receiving antiretroviral therapy.

$\mathrm{PVL}=$ plasma viral load and $\mathrm{SVL}=$ seminal viral load. Median \pm SEM (standard of the mean).

Only 9/36 (25\%) patients presented both PVL and SVL below the assay's detection limit after 6 months of antiretroviral therapy, 2 patients receiving 2-drug regimens and 7 on 3-drug combinations (Table 2). At 6 months, 13 patients presented discordant HIV-1 viral loads, 6/36 (17\%) had non-detectable PVL but detectable SVL (1 patient receiving 2-drug and 5 on 3-drug regimens). On the other hand, $7 / 36(19 \%)$ patients presented non-detectable SVL but a detectable PVL (2 patients receiving 2-drug combinations and 5 on 3-drug regimens) (Table 1).

\section{DISCUSSION}

In the present work, we investigated the impact of anti-retroviral therapy on CD4 counts, PVL and SVL in 36 patients with HIV infection during a 6-month period after treatment initiation. In our study, the mean increase in CD4 counts after 6 months of treatment was lower than that previously reported ${ }^{12}{ }^{15}$. This difference was probably due to the fact that a subset of patients had received a 2-drug regimen during followup. In fact, when only patients taking 3-drug (24/36) were considered, an increase of $161 \mathrm{CD}^{+}$cells/ $\mu$ l was observed, which is similar to the improvement (150 $\mathrm{CD} 4^{+}$cells/ul) previously reported by Schooley et al ${ }^{15}$. After 6 months of antiretroviral therapy, 25\% of patients (9/36) had undetectable PVL and SVL, 2 treated with 2-drug regimens and 7 with a 3-drug combination (Table 2). Some patients presented discordant HIV-1 viral loads, $6 / 36(17 \%)$ had non-detectable PVL but detectable SVL and 7 (19\%) presented non-detectable SVL but a detectable PVL. Fifteen out of 36 treated patients $(42 \%)$ had PVL below the detection limit after 6 months of therapy. Again, if separated according to their therapeutic schemes, $25 \%(3 / 12)$ of the patients taking 2 drugs and $50 \%(12 / 24)$ of the patients taking 3 drugs had non-detectable PVL. The difference between the two groups was not significant $(p=0.27)$, probably due to the size of our cohort.

At baseline, when patients were grouped according to their CD4 cell counts, correlation between PVL and
SVL was dependent on the CD4 cell counts. No correlation between PVL and SVL was observed among patients with CD4 counts below $200 \mathrm{CD}^{+}$cells/ $\mu \mathrm{l}$. However, after 6 months of treatment, the correlation between PVL and SVL was no longer dependent on $\mathrm{CD} 4^{+}$cell counts (data not shown). During treatment, a similar decrease was observed in both PVL and SVL $(p=0.21)$, confirming previously published results indicating an overall correlation between PVL and SVL ${ }^{417}$. Although discordant HIV-1 viral load titers were observed in plasma and semen samples from several patient samples after 6 months of therapy, VL was below the detection limit in plasma but detectable in semen samples from 6 patients (patients \# 14, 18, 19, 26, 27 and 30) and VL was below the detection limit in semen but detectable in plasma in another 7 patients (patients \# 2, 7, 12, 21, 23, 25 and 36). The discordance observed in these 13 patients, corroborates the idea of HIV compartmentalization, which may be characterized by an imperfect correlation between blood and seminal compartments. Blood and seminal compartmentalization of HIV infection, may explain, in part, the differences in sexual transmission rates observed among different populations. Recently, Quinn et al. reported that an important correlation between plasma viral load and heterosexual transmission of HIV was observed among seropositive men in Sub-Saharan Africa ${ }^{14}$. 
Table $2-C D 4^{+}$cell counts and viral load determination at baseline, 45, 90 and 180 days of antiretroviral therapy*.

\begin{tabular}{|c|c|c|c|c|c|c|c|c|c|c|c|c|c|}
\hline \multirow[t]{2}{*}{ Patients } & \multicolumn{3}{|c|}{ Baseline } & \multicolumn{3}{|c|}{45 days } & \multicolumn{3}{|c|}{90 days } & \multicolumn{3}{|c|}{180 days } & \multirow[b]{2}{*}{ Therapy** } \\
\hline & $\mathrm{CD}^{+}{ }^{+}$ & PVL & SVL & $\mathrm{CD}^{+}+$ & PVL & SVL & $\mathrm{CD}^{+}+$ & PVL & SVL & $\mathrm{CD} 4^{+}$ & PVL & SVL & \\
\hline 1 & 216 & 5.04 & 5.21 & 712 & 3.68 & 3.8 & 672 & 3.11 & $\mathrm{BDL}$ & 561 & $\mathrm{BDL}$ & BDL & $2 \mathrm{RTI}+\mathrm{PI}$ \\
\hline 2 & 378 & 4.38 & 4.41 & 529 & 2.83 & 3.28 & 526 & $\mathrm{BDL}$ & 3.9 & 530 & 3.45 & $\mathrm{BDL}$ & 2 RTI \\
\hline 3 & 59 & 5.63 & 4.28 & 115 & 5.04 & $\mathrm{BDL}$ & 143 & 4.08 & 4.18 & 47 & 2.86 & 5.11 & $2 \mathrm{RTI}+\mathrm{Pl}$ \\
\hline 4 & 844 & 4.79 & 4.7 & 763 & 2.86 & $\mathrm{BDL}$ & 889 & 2.94 & $\mathrm{BDL}$ & 1192 & 3.15 & 3.11 & 2 RTI \\
\hline 5 & 168 & 5.76 & 5.76 & 220 & 4.56 & 4.86 & 419 & 4.4 & 3.6 & 336 & 4.11 & 3.74 & $2 \mathrm{RTI}$ \\
\hline 6 & 400 & 4.66 & 4.85 & 519 & 3.38 & $\mathrm{BDL}$ & 583 & $\mathrm{BDL}$ & $\mathrm{BDL}$ & 522 & $\mathrm{BDL}$ & $\mathrm{BDL}$ & $2 \mathrm{RTI}+\mathrm{PI}$ \\
\hline 7 & 200 & 5.45 & 5.18 & 291 & 4.41 & $\mathrm{BDL}$ & 211 & 3.27 & 2.78 & 268 & 2.9 & $\mathrm{BDL}$ & $2 \mathrm{RTI}+\mathrm{PI}$ \\
\hline 8 & 811 & 4.2 & 5.28 & 704 & 2.83 & 4.28 & 868 & $\mathrm{BDL}$ & $\mathrm{BDL}$ & 703 & $\mathrm{BDL}$ & BDL & $2 \mathrm{RTI}$ \\
\hline 9 & 191 & 3.51 & 3.41 & 77 & 4.41 & 3.83 & 93 & 2.67 & $\mathrm{BDL}$ & 68 & 3.04 & 3.78 & $2 \mathrm{RTI}+\mathrm{PI}$ \\
\hline 10 & 48 & 5.92 & 5.29 & 165 & 2.78 & $\mathrm{BDL}$ & 187 & 5.04 & 4.2 & 98 & 5.83 & 4.66 & $2 \mathrm{RTI}+\mathrm{PI}$ \\
\hline 11 & 361 & 4.11 & 3.53 & 441 & 3.18 & $\mathrm{BDL}$ & 641 & 2.99 & $\mathrm{BDL}$ & 535 & 3.66 & 3.66 & 2 RTI \\
\hline 12 & 94 & 5.49 & 3.64 & 400 & 2.97 & $\mathrm{BDL}$ & 432 & $\mathrm{BDL}$ & $\mathrm{BDL}$ & 281 & 4.46 & $\mathrm{BDL}$ & $2 \mathrm{RTI}+\mathrm{PI}$ \\
\hline 13 & 348 & 5.08 & 3.88 & 516 & 4.9 & 3.76 & 524 & 2.95 & 4.29 & 628 & $\mathrm{BDL}$ & BDL & $2 \mathrm{RTI}+\mathrm{PI}$ \\
\hline 14 & 514 & 4.18 & 4.38 & 800 & BDL & $\mathrm{BDL}$ & 878 & $\mathrm{BDL}$ & $\mathrm{BDL}$ & 953 & $\mathrm{BDL}$ & 3.53 & 2 RTI \\
\hline 15 & 479 & 4.95 & 4.95 & 380 & 5.11 & 4.98 & 352 & 3.83 & 4.96 & 338 & 5.23 & 3.89 & $2 \mathrm{RTI}$ \\
\hline 16 & 189 & 4.95 & 5.17 & 335 & 3.04 & $\mathrm{BDL}$ & 296 & 2.67 & $\mathrm{BDL}$ & 310 & $\mathrm{BDL}$ & BDL & $2 \mathrm{RTI}+\mathrm{Pl}$ \\
\hline 17 & 603 & 4.76 & 4.41 & 907 & BDL & BDL & 785 & $\mathrm{BDL}$ & $\mathrm{BDL}$ & 737 & 2.88 & 3.58 & $2 \mathrm{RTI}+\mathrm{PI}$ \\
\hline 18 & 421 & 5.18 & 5.21 & 548 & $\mathrm{BDL}$ & $\mathrm{BDL}$ & 446 & 3.23 & $\mathrm{BDL}$ & 724 & $\mathrm{BDL}$ & 2.88 & $2 \mathrm{RTI}+\mathrm{PI}$ \\
\hline 19 & 36 & 5.2 & 5.34 & 198 & 3.15 & $\mathrm{BDL}$ & 239 & $\mathrm{BDL}$ & $\mathrm{BDL}$ & 203 & $\mathrm{BDL}$ & 3.2 & $2 \mathrm{RTI}+\mathrm{PI}$ \\
\hline 20 & 139 & 4.3 & 5.45 & 219 & BDL & 3.26 & 135 & $\mathrm{BDL}$ & $\mathrm{BDL}$ & 189 & $\mathrm{BDL}$ & $\mathrm{BDL}$ & $2 \mathrm{RTI}+\mathrm{PI}$ \\
\hline 21 & 152 & 4.91 & 3.04 & 720 & 4.7 & $\mathrm{BDL}$ & 348 & 3.71 & $\mathrm{BDL}$ & 169 & 3.87 & BDL & $2 \mathrm{RTI}+\mathrm{PI}$ \\
\hline 22 & 119 & 5.86 & 4.48 & 274 & $\mathrm{BDL}$ & 4 & 421 & $\mathrm{BDL}$ & $\mathrm{BDL}$ & 480 & $\mathrm{BDL}$ & $\mathrm{BDL}$ & $2 \mathrm{RTI}+\mathrm{PI}$ \\
\hline 23 & 133 & 5.48 & 4.51 & 384 & 3.38 & 4.26 & 368 & 2.63 & 4.51 & 302 & $\mathrm{BDL}$ & 2.97 & $2 \mathrm{RTI}+\mathrm{PI}$ \\
\hline 24 & 229 & 5.57 & 5.26 & 258 & 3.08 & 3.27 & 205 & 4.23 & 4.45 & 230 & 3.67 & BDL & $2 \mathrm{RTI}+\mathrm{PI}$ \\
\hline 25 & 964 & 4.61 & 5.06 & 449 & 4.45 & 3.84 & 729 & 4.11 & 4.64 & 508 & 4.2 & 4.69 & $2 \mathrm{RTI}$ \\
\hline 26 & 32 & 4.62 & 3.68 & 264 & $\mathrm{BDL}$ & $\mathrm{BDL}$ & 209 & $\mathrm{BDL}$ & $\mathrm{BDL}$ & 225 & 2.7 & $\mathrm{BDL}$ & $2 \mathrm{RTI}+\mathrm{PI}$ \\
\hline 27 & 380 & 5.04 & 3.76 & 432 & 2.75 & 3.56 & 448 & 3.52 & 4.12 & 496 & $\mathrm{BDL}$ & 2.72 & $2 \mathrm{RTI}+\mathrm{PI}$ \\
\hline 28 & 48 & 4.81 & 6.11 & 296 & 3.04 & 4.92 & 248 & 4.41 & 4.62 & 254 & 4.07 & 4.38 & $2 \mathrm{RTI}+\mathrm{PI}$ \\
\hline 29 & 235 & 5.76 & 5.56 & 345 & 3.23 & 4.18 & 372 & $\mathrm{BDL}$ & 3.3 & 556 & $\mathrm{BDL}$ & $\mathrm{BDL}$ & $2 \mathrm{RTI}+\mathrm{PI}$ \\
\hline 30 & 322 & 5.04 & 3.76 & 419 & 4.56 & 4.86 & 512 & 3.15 & 3.9 & 550 & $\mathrm{BDL}$ & 4.69 & $3 \mathrm{RTI}$ \\
\hline 31 & 279 & 5.04 & 4.18 & 396 & 2.86 & $\mathrm{BDL}$ & 380 & 2.86 & 3.07 & 696 & 3.66 & 3.41 & $2 \mathrm{RTI}+\mathrm{PI}$ \\
\hline 32 & 297 & 4.68 & 4.08 & 288 & 2.9 & 3.58 & 310 & $\mathrm{BDL}$ & 2.91 & 444 & 3.71 & 4.11 & 3 RTI \\
\hline 33 & 688 & 4.2 & 3.6 & 420 & 3.07 & BDL & 546 & 3.08 & BDL & 365 & 4.26 & 4.4 & 2 RTI \\
\hline 34 & 588 & 4.66 & 3.92 & 792 & BDL & BDL & 800 & 3.32 & 4.77 & 793 & $\mathrm{BDL}$ & BDL & 2 RTI \\
\hline 35 & 54 & 4.93 & 3.92 & 120 & BDL & $\mathrm{BDL}$ & 183 & 3.52 & 4.1 & 190 & 3.04 & 3.34 & $2 \mathrm{RTI}$ \\
\hline 36 & 232 & 3.86 & 4.11 & 244 & BDL & $\mathrm{BDL}$ & 336 & 4.18 & 4.08 & 206 & 3.86 & BDL & $2 \mathrm{RTI}$ \\
\hline
\end{tabular}

Our study confirms the decline in SVL after antiretroviral therapy as described by other authors ${ }^{161118}$. However, the lack of correlation between PVL and SVL in a significant number of patients in our cohort suggests that, in a clinical setting, when inhibition of $\mathrm{HIV}-1^{+}$replication in blood plasma is achieved it may not be the case in another compartment, such as germinal tissues. Clearly, it may amplify the risk of development of drug-resistant mutants as described before ${ }^{9}$. Therefore, more studies are needed to fully investigate the efficacy of antiretroviral therapy on HIV load in semen from HIV$1^{+}$patients and its impact on viral shedding.

\section{REFERENCES}

1. Barroso PF, Schechter M, Gupta P, Melo MF, Vieira M, Murta FC, Souza $Y$, Harrison LH. Effect of antiretroviral therapy on HIV shedding in semen. Annals of Internal Medicine 133: 280284, 2000.

2. Centers for Diseases Control and Prevention. 1993 revised classification system for HIV infection and expanded surveillance case definition for AIDS among adolescents and adults. Mortality and Morbidity Weekly Report 41: 1-19, 1992.

3. Dyer JR, Eron JJ, Hoffman, IF, Kazembe P, Vernazza PL, Nkata E, Costello Daly C, Fiscus SA, Cohen MS. Association of CD4 cell depletion and elevated blood and seminal plasma human immunodeficiency virus type 1 (HIV-1) RNA concentrations with 
genital ulcer disease in HIV-1-infected men in Malawi. Journal of Infectious Diseases 177: 224-227, 1998 a

4. Dyer JR, Gillian BL, Eron JR JJ, Grosso L, Cohen MS, Fiscus SA. Quantitation of human immunodeficiency virus type 1 RNA in cell free seminal plasma: comparison of NASBA with Amplicor reverse transcription-PCR amplification and correlation with quantitative culture. Journal of Virological Methods 60: 161170, 1996.

5. Dyer JR, Kazembe P, Vernazza PL, Gilliam BL, Maida M, Zimba D, Hoffman IF, Royce RA, Schock JL, Fiscus SA, Cohen MS, Eron JJ Jr. High levels of human immunodeficiency virus type 1 in blood and semen of seropositive men in Sub-Saharan Africa. Journal of Infectious Diseases 177: 1742-1746, 1998 .

6. Gilliam BL, Dyer JR, Fiscus SA, Marcus C, Zhou S, Wathen L, Freimuth WW, Cohen MS, Eron JJ Jr. Effects of reverse transcriptase inhibitor therapy on the HIV-1 viral burden in semen. Journal of Acquired Immune Deficiency Syndrome and Human Retrovirology 15: 54-60, 1997.

7. Gupta P, Mellors J, Kingsley L, Riddler S, Singh MK, Schreiber $S$, Cronin M, Rinaldo CR. High viral load in semen of human immunodeficiency virus type 1 -infected men at all stages of disease and its reduction by therapy with protease and nonnucleoside reverse transcriptase inhibitors. Journal of Virology 71: 6271-6275, 1997.

8. Ho DD, Schooley RT, Rota TR, Kaplan JC, Flynn T, Salahuddin SZ, Gonda MA, Hirsch MS. HTLV-III in the semen and blood of a healthy homosexual man. Science 226: 451-453, 1984.

9. Mayer KH, Boswell S, Goldstein R, Lo W, Xu C, Tucker L, DePasquale MP, D'Aquila R, Anderson DJ. Persistence of human immunodeficiency virus in semen after adding indinavir to combination antiretroviral therapy. Clinical Infectious Diseases 28: 1252-1259, 1999.

10. Ministério da Saúde. Coordenação Nacional de DST/AIDS. Guia de tratamento clínico das infeções pelo HIV em adultos e adolescentes. Brasília, 1997.
11. Musicco M, Lazzarin A, Nicolosi A, Gasparini M, Costigliola P, Arici C, Saracco A. Antiretroviral treatment of men infected with human immunodeficiency virus type 1 reduces the incidence of heterosexual transmission. Archives of Internal Medicine 154: 1971-1976, 1994.

12. Pakker NG, Notermans DW, de Boer RJ, Roos MT, de Wolf $F$, Hill A, Leonard JM, Danner SA, Miedema F, Schellekens PT. Biphasic kinetics of peripheral blood $T$ cells after triple combination therapy in HIV-1 infection: a composite of redistribution and proliferation. Nature Medicine 4: 208-214, 1998.

13. Pinto-Neto LF, Vieira NF, Soprani M, Cunha CB, Dietze R, Ribeiro-Rodrigues $R$. Lack of correlation between seminal and plasma HIV- 1 viral loads is associated with CD4 T cell depletion in therapy-naive HIV-1+ patients. Memórias do Instituto Oswaldo Cruz 97:563-567, 2002.

14. Quinn TC, Wawer MJ, Sewankambo N, Serwadda D, Li C, Wabwire-Mangen F, Meehan MO, Lutalo T, Gray RH. Viral load and heterosexual transmission of human immunodeficiency virus type 1. Rakai Project Study Group. New England Journal of Medicine 342: 921-929, 2000.

15. Schooley RT. Longer-term immunologic effects and side effects of successful antiretroviral therapy. Clinical Infectious Diseases 29: 12-18, 1999.

16. van Gemen B, van Beuningen $R$, Nabbe A, van Strijp D, Jurriaans $S$, Lens $P$, Kievits $T$. A one-tube quantitative HIV-1 RNA NASBA nucleic acid amplification assay using electrochemiluminescent $(E C L)$ labelled probes. Journal of Virological Methods 49: 157-168, 1994.

17. Vernazza PL, Dyer JR, Fiscus SA, Eron JJ, Cohen MS. HIV-1 viral load in blood, semen and saliva. [Letter] AIDS 11: 10581059, 1997.

18. Vernazza PL, Gilliam BL, Flepp M, Dyer JR, Frank AC, Fiscus SA, Cohen MS, Eron JJ. Effect of antiviral treatment on the shedding of HIV-1 in semen. AIDS 11: 1249-54, 1997. 